\title{
Reaksi Pasar Modal Terhadap Pengumuman Right Issue pada Perusahaan yang Terdaftar di Bursa Efek Indonesia
}

\author{
Pita Qurnia Amir ${ }^{1}$ \\ I G.N. Agung Suaryana ${ }^{2}$ \\ ${ }^{1,2}$ Fakultas Ekonomi dan Bisnis Universitas Udayana (Unud), Bali, Indonesia \\ e-mail: pitaqa@yahoo.com
}

\begin{abstract}
ABSTRAK
Penelitan ini bertujuan untuk mengetahui ada tidaknya reaksi pasar terhadap pengumuman right issue. Penelitian ini dilakukan di Bursa Efek Indonesia (BEI) pada perusahaan go public yang melakukan right issue selama periode 2011-2017 dengan jumlah populasi sebanyak 143 perusahaan. Pemilihan sampel menggunakan metode observasi non partisipan dengan teknik purposive sampling, diperoleh sampel sebanyak 103 perusahaan. Teknik analisis yang digunakan adalah uji one sample t-test pada cumulative abnormal return. Berdasarkan hasil analisis yang dilakukan ditemukan bahwa tidak ada reaksi pasar terhadap pengumuman right issue, yang berarti pengumuman right issue tidak memiliki kandungan informasi sehingga tidak memengaruhi prefensi investor dalam mengambil keputusan.
\end{abstract}

Kata kunci: Right issue, abnormal return, reaksi pasar.

\begin{abstract}
This research aims to determine whether there is a market reaction to the announcement of the rights issue. This research was conducted on the Indonesia Stock Exchange (IDX) in publicly listed companies that conducted rights issues during the period 2011-2017 with a population of 143 companies. The sample selection uses non-participant observation method with purposive sampling technique, obtained a sample of 103 companies. The analysis technique used is to test one sample t-test on the cumulative abnormal return. Based on the results of the analysis conducted, it was found that there is no market reaction to the announcement of the rights issue, which means the announcement of the rights issue does not have information content so it does not affect the investor's preference in making decisions.

Keywords: Right issue, abnormal return, market reaction.
\end{abstract}

\section{PENDAHULUAN}

Pasar modal telah menjadi instrumen perekonomian yang sangat penting. Pasar modal merupakan tempat dimana berbagai pihak khususnya perusahaan menjual saham (stock) dan obligasi (bond) dengan tujuan dari hasil penjualan tersebut nantinya akan diperdagangkan sebagai tambahan dana atau untuk memperkuat modal perusahaan. Perusahaan membutuhkan dana untuk bekerja secara efektif dengan tujuan untuk membantu keberlangsungan operasional perusahaan (Khoso 
et al., 2016). Dana yang memadai memungkinkan perusahaan beroperasi secara efisien (Ogada \& Kalunda, 2017). Keberadaan pasar modal menguntungkan bagi emiten dan investor (Alisabri, 2004). Dengan keberadaan pasar modal, diharapkan aktivitas perekonomian dapat mengalami peningkatan karena pasar modal merupakan alternatif pendanaan bagi perusahaan, sehingga dapat beroperasi dengan skala yang besar, dan kemudian akan meningkatkan pendapatan perusahaan dan kemakmuran masyarakat luas.

Perkembangan perekonomian dunia maupun Indonesia ini mulai mengalami perkembangan menjadi lebih baik. Perekonomian yang semakin berkembang ini membuat perusahaan-perusahaan lebih gencar dalam melakukan pengembangan usaha dan pengembangan produk agar lebih dikenal oleh masyarakat luas. Pengembangan usaha yang dilakukan oleh perusahaan tentunya memerlukan biaya yang tidak sedikit (Fahmi \& Saputra, 2013). Perusahaan yang masih memiliki kebutuhan dana setelah go public untuk meningkatkan modal disetor dapat menambah kebutuhan dana melalui corporate action atau aksi korporasi. Menurut Tambunan (2007: 41), corporate action adalah aksi yang dilakukan perusahaan, yang berdampak signifikan terhadap berbagai kepentingan, antara lain kelangsungan operasi perusahaan, harga saham serta pemegang saham. Corporate action diajukan oleh dewan direksi perusahaan dalam Rapat Umum Pemegang Saham (RUPS), untuk mendapat persetujuan dari pemegang saham. Selanjutnya emiten wajib melaporkan rencana corporate action tersebut kepada BAPEPAM dan Bursa Efek, serta diumumkan di pasar modal. Perusahaan yang terdaftar di Bursa Efek mengumumkan peristiwa penting yang kemudian 
akan memengaruhi keputusan investasi para investor (Kendirli \& Elmali, 2016). Salah satu bentuk dari corporate action adalah menerbitkan right issue dengan tujuan untuk memperoleh tambahan dana bagi emiten yang sudah tercatat di Bursa.

Right issue adalah preemptive right dimana pemegang saham lama memiliki hak untuk menjaga kepemilikan saham di perusahaan dan right hanya bersifat hak dan bukan suatu kewajiban, jika pemegang saham tidak melaksanakan, maka right akan diperdagangkan di bursa, hanya saja perdagangan right memiliki keterbatasan masa berlakunya. Right issue membuat investor lama memiliki hak khusus yaitu hak membeli efek terlebih dahulu atas saham-saham baru yang dikeluarkan oleh emiten dengan proporsi dan harga tertentu dengan tujuan mempertahankan proporsi kepemilikannya di perusahaan tetapi karena hal tersebut merupakan hak, maka investor tidak terikat untuk membelinya dan ia dapat menjual haknya kepada orang lain.

Right issue merupakan cara yang paling diminati perusahaan untuk menghimpun dana karena untuk melakukan right issue perusahaan tidak perlu menanggung biaya penjamin emisi efek seperti halnya penawaran umum perdana (Mariko \& Theuri, 2016). Perusahaan akan cenderng melakukan right issue sebab manfaat yang akan didapat lebih besar daripada biaya yang harus dikeluarkan Frijns et al., (2016) dalam (Dewi \& Putra, 2013). Berdasarkan data yang diperoleh dari website www.ojk.go.id, pada tahun 2017, emisi yang dihasilkan melalui right issue jauh lebih besar dibandingkan nilai emisi yang dihasilkan melalui initial public offering (IPO). Emisi right issue mencapai Rp 82.69 triliun, sedangkan 
emisi yang diperoleh melalui initial public offering (IPO) jauh di bawah yaitu hanya sebesar Rp 9.49 triliun.

Tabel 1.

Jumlah Emisi yang dihasilkan melalui Initial Public Offering (IPO) dan Right Issue Tahun 2016 dan 2017

\begin{tabular}{lrr}
\hline & 2016 & 2017 \\
\hline EMISI & & \\
Saham (Rp Triliun) & 79.19 & 97.79 \\
IPO saham & 12.07 & 9.49 \\
Rights & 67.12 & 82.69 \\
\hline
\end{tabular}

Sumber: Data diolah, 2017

Fenomena tersebut didukung dengan pernyataan yang dikutip melalui website. Sebanyak 17 Emiten akan menerbitkan right issue (hak memesan efek terlebih dahulu/HMETD) senilai lebih dari Rp 65 triliun. Lesunya perekonomian domestik, antisipasi ketidakpastian global dampak kebijakan Presiden Amerika Serikat, Donald Trump yang cenderung protektif dan kenaikan suku bunga The Fed mendorong korporasi mencari dana murah di bursa saham. Sebab, kenaikan suku bunga bank sentral Amerika dapat berdampak terhadap naiknya suku bunga pinjaman. Selain untuk menambah permodalan, sebagian emiten mencari pendanaan untuk melakukan ekspansi ataupun membayar utang. Beberapa bank melakukan right issue untuk meningkatkan modal agar bisa naik kelas berdasarkan bank umum kelompok usaha (BUKU). PT Bumi Resources Tbk (BUMI) juga berencana menerbitkan right issue dengan harga indikasi Rp 926 per saham dan target $\mathrm{Rp} 35$ triliun yang akan digunakan untuk mengkonversi utangnya menjadi kepemilikan saham (databoks.katadata.co.id,2017). 


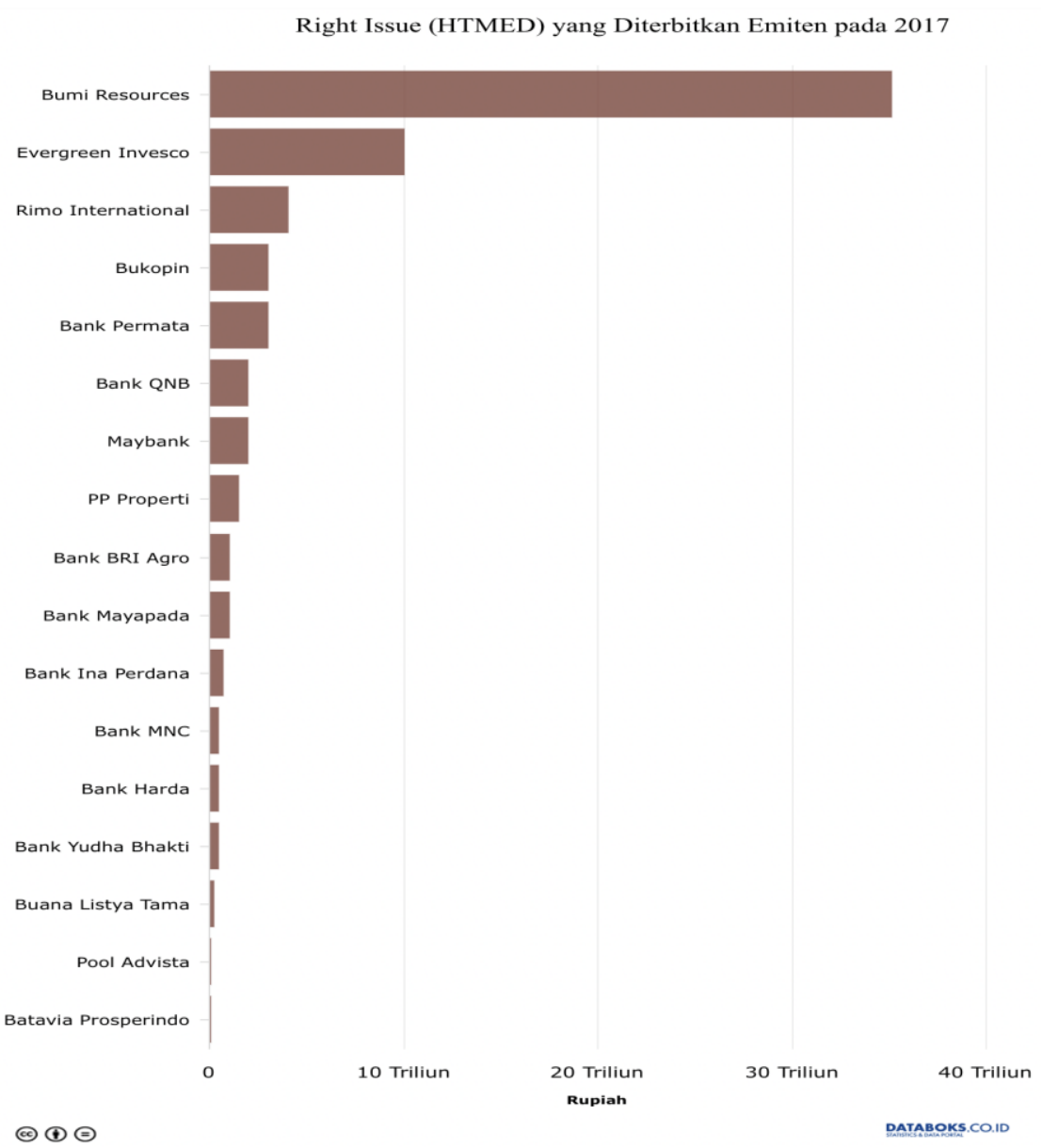

Gambar 1. Right Issue yang Distribusikan Emiten Tahun 2017 Sumber: Databoks.katadata.co.id, 2017

Kondisi pasar yang sedang volatile tidak menghalangi beberapa emiten untuk tidak meghimpun dana dari pasar modal. Meraup dana melalui right issue dinilai lebih murah daripada merilis surat utang maupun mengajukan pinjaman ke perbankan. Kepala Riset Ekuator Swarna Sekuritas David Sutyanto menilai, Right issue lebih diminati emiten karena beberapa alasan. Pertama, emiten meraup dana segar dengan murah daripada menerbitkan obligasi atau utang bank. Kedua, emiten dapat menjaring investor baru. Ketiga, dengan rights issue emiten ingin memasukkan aset baru (www.ivestasi.kontan.co.id, 2018). 
Pengumuman right issue akan menimbulkan reaksi pasar jika terdapat kandungan informasi didalamnya yang dapat menjadi pertimbangan investor dalam berinvestasi. Reaksi pasar saham mewakili kepercayaan investor tentang nilai perusahaan (Malhotra et al., 2012). Kurniasari dan Nugraheni dalam Lianawati \& Darmayanti (2015) menyatakan bahwa secara teoritis harga sekuritas setelah pengumuman right issue akan mengalami penurunan, karena harga saham dalam pelaksanaan right issue selalu lebih rendah dari harga pasar. Dengan demikian, kapitalisasi pasar sekuritas akan naik dalam persentase yang lebih kecil daripada persentase jumlah saham yang beredar. Right issue akan berdampak terhadap meningkatnya penawaran jumlah saham beredar, yang selanjutnya secara temporer akan menurunkan harga saham. Apabila pemegang saham lama tidak menggunakan haknya untuk membeli saham baru, maka ia akan mengalami penurunan persentase kepemilikan saham, atau dikenal dengan istilah dilusi (dilution).

Yusi dalam Rizaldi (2014) menyatakan pendanaan melalui right issue memberikan reaksi pasar ganda bagi fluktuasi harga saham. Pertama, harga saham akan berfluktuasi setelah diumumkannya right issue. Kedua, harga saham juga akan berfluktuasi setelah masa berlaku penawaran (cum date) atau pada saat penawaran tidak berlaku lagi (ex date). Hal ini disebabkan investor mengambil sikap antisipasi terhadap adanya informasi yang merupakan good news atau bad news bagi investor. Apabila penggunaan dana hasil right issue digunakan untuk perluasan usaha maka ini dianggap sebagai sinyal positif atau kabar baik bagi investor. Karena bisa memberikan keuntungan di masa mendatang. Sinyal negatif 
atau kabar buruk terjadi bila pengumpulan dana hasil right issue digunakan untuk menutupi biaya-biaya perusahaan atau bahkan untuk membayar utang perusahaan. Karena adanya reaksi pasar yang muncul akibat dari pengumuman right issue maka investor akan mempertimbangkan sebagai informasi yang bernilai dan mampu mempengaruhi investor dalam bertransaksi di pasar modal. Apabila suatu pengumuman yang di publikasikan di pasar modal mengandung informasi maka akan terjadi reaksi pasar. Reaksi pasar ini dapat tercermin dari perubahan abnormal return.

Pengambilan keputusan investasi oleh para investor yang rasional tentu akan dipengaruhi oleh risiko dan tingkat keuntungan yang diharapkan (expected return) dari investasinya. Untuk dapat memperoleh gambaran mengenai risiko dan tingkat keuntungan dari investasinya tersebut, seorang investor tentu membutuhkan informasi yang lebih banyak tentang suatu perusahaan. Informasi tersebut termasuk dalam informasi yang bersifat kuantitatif maupun yang bersifat kualitatif (Solikhin, 2000). Informasi tersebut akan memiliki nilai bagi investor jika keberadaan informasi tersebut mampu membuat investor melakukan transaksi di pasar modal atau dengan kata lain jika pengumuman right issue yang dikeluarkan mempunyai kandungan informasi yang cukup, maka pengumuman itu akan mempengaruhi preferensi investor dalam pembuatan keputusan investasinya. Berdasarkan informasi yang relevan, investor dapat menilai prospek kinerja emiten sehingga investor memiliki gambaran mengenai risiko dan expected return atas dana yang telah atau akan diinvestasikan. Respon pasar oleh investor terhadap informasi baru merupakan hal yang perlu diperhatikan oleh perusahaan, 
Pita Qurnia Amir dan I G.N. Agung Suaryana. Reaksi ...

karena harga dari saham perusahaan akan bergantung pada investor. Suatu peristiwa yang memiliki informasi buruk biasanya akan direspon negatif oleh pasar dan peristiwa yang memiliki informasi baik akan direspon positif oleh pasar. Suatu peristiwa yang memiliki kandungan informasi relevan bagi investor akan menimbulkan reaksi pasar yang tercermin melalui perubahan harga saham (Hartono, 2015: 624).

Pengujian kandungan informasi suatu peristiwa seperti peristiwa pengumuman right issue biasanya menggunakan event study. Hartono (2015: 623) mendefinisikan, studi peristiwa (event study) merupakan studi yang mempelajari reaksi pasar terhadap suatu peristiwa (event) yang informasinya dipublikasikan sebagai suatu pengumuman, dimana dalam penelitian ini adalah peristiwa pengumuman right issue. Ada tidaknya pengaruh tersebut dapat dilihat dari ada tidaknya abnormal return yang signifikan di sekitar tanggal pengumuman right issue. Abnormal return merupakan kelebihan return yang sesungguhnya (actual return) terhadap return normal, return normal merupakan return ekspektasian atau return yang diharapkan investor. Return sesungguhnya (actual return) adalah return yang terjadi pada waktu ke-t yang merupakan selisih harga sekarang relatif terhadap harga saham sebelumnya (Hartono, 2015: 648). Apabila terdapat abnormal return di sekitar tanggal pengumuman, berarti pengumuman right issue merupakan pengumuman yang dapat mempengaruhi pasar.

Penelitian mengenai right issue telah banyak dilakukan, tetapi hasil yang ditunjukkan masih memperlihatkan hasil yang berbeda-beda. Penelitian yang dilakukan oleh Babu (2018) serta Dewi \& Putra (2013) menunjukkan bahwa right 
issue tidak berpengaruh secara signifikan terhadap abnormal return perusahaanperusahaan yang melakukan right issue. Endriani (2015), Komaling (2010), Kusuma \& Suryanawa (2015), Lianawati \& Darmayanti (2015), Widaryanti (2006) juga meneliti tentang right issue dan hasilnya menunjukkan bahwa abnormal return tidak terdapat perubahan sebelum dan sesudah right issue.

Namun berbeda dengan penelitian yang dilakukan oleh Manullang (2008), Yusuf et al., (2009) dan Miglani (2011) yang memberikan kesimpulan bahwa right issue berpengaruh signifikan terhadap abnormal return. Ginglinger \& Gajewski (2007). Shahid et al., (2010) juga menyatakan terdapat reaksi pasar atas pengumuman right issue yang ditunjukan dengan perbedaan abnormal return secara signifikan di sekitar pengumuman right issue.

Pecking order theory mampu menjelaskan preferensi perusahaan dalam menentukan struktur modal optimal. Menurut Myers (1984) dalam jurnal The Capital Structure Puzzle menyatakan bahwa ada semacam tata urutan (pecking order) bagi perusahaan dalam menggunakan modal, yaitu perusahaan lebih menyukai internal financing (pendanaan dari hasil operasi perusahaan, yang berwujud laba ditahan) daripada external financing (menerbitkan saham baru). Penggunaan laba yang ditahan dinilai lebih murah dan perusahaan tidak perlu mengungkapkan sejumlah informasi perusahaan yang harus diungkapkan saat menerbitkan obligasi maupun saham baru. Perusahaan memiliki opsi untuk menggunakan hutang atau ekuitas untuk membiayai operasi mereka (Otieno \& Ochieng, 2015). Apabila dana dari luar (external financing) diperlukan maka perusahaan akan menggunakan hutang sebelum menerbitkan saham baru. 
Penerbitan saham juga berakibat pada turunnya dividen perlembar saham dan turunya harga atau nilai saham karena jumlah saham bertambah. Akibatnya jika pendanaan eksternal dilakukan ddengan penerbitan saham baru akan mendapat apresiasi atau respon negatif oleh pasar.

Myers (1984) di dalam pecking order theory juga menyatakan bahwa permasalahan utama keputusan struktur modal perusahaan adalah informasi yang tidak simetris (assymetric information) di antara manajer dan investor mengenai kondisi internal perusahaan, serta argumentasi bahwa manajer berpihak kepada para pemegang saham lama. Kedua permasalahan tersebut menyebabkan perusahaan memiliki hierarki pendanaan yang dimulai dari arus kas internal, utang, kemudian penerbitan saham. Pecking order theory merupakan teori yang dapat menjelaskan mengapa perusahaan meminjam jumlah uang yang lebih sedikit. Pecking order theory berdasarkan asumsi asimetris, manajer tahu lebih banyak daripada investor tentang profitabilitas dan prospek perusahaan. Maka investor mungkin tidak dapat menilai sebenarnya dari penerbitan sekuritas baru oleh perusahaan.

Mereka terutama enggan membeli saham biasa yang baru diterbitkan, karena para manajer khawatir bahwa saham baru itu ternyata dihargai terlalu tinggi. Kekhawatiran semacam itu dapat menjelaskan mengapa pengumuman penerbitan saham dapat menurunkan harga saham. Jika manajer tahu lebih banyak daripada investor luar, para manajer akan tergiur mengatur waktu penerbitan saham ketika saham perusahaan mereka dihargai terlalu tinggi (overvalued) dengan kata lain, ketika manajer relatif pesimistis. Di pihak lain, manajer yang 
optimis akan melihat harga saham perusahaan mereka diharga terlalu rendah (undervalued) dan memutuskan untuk tidak menerbitkan. Masalah yang timbul dari penerbitan saham dapat dihindari jika perusahaan dapat mendanai dengan dana internal, yaitu dengan laba yang ditahan diinvestasikan kembali. Tetapi jika diperlukan pendanaan eksternal, jalur terakhir adalah penerbitan utang, bukan ekuitas. Penerbitan utang tampaknya memiliki dampak kecil pada harga saham. Ruang lingkup kesalahan penilaian utang lebih kecil dan karena itu, penerbitan utang merupakan tanda yang tidak terlalu mengkhawatikan investor.

Darmadji \& Fakhruddin (2006) menyatakan right atau Hak Memesan Efek Terlebih Dahulu (HMETD) merupakan bapepam berharga yang memberikan hak kepada pemegangnya untuk menukarkannya (exercise) menjadi saham biasa. Right issue diberikan kepada para pemegang saham sehubungan dengan proses pengeluaran saham baru. Ketika terjadi right issue, maka pemegang saham lama (existing shareholder) memiliki hak lebih utama (preemptive right) atas saham baru yang dikeluarkan perusahaan. Skema ini bertujuan menjaga agar pemegang saham lama tidak mengalami penurunan persentase kepemilikan (dilusi) sehubungan dengan penerbitan saham baru sesuai dengan pertimbangan yang ada (Ventoruzzo, 2013).

Pasar modal adalah pertemuan antara pihak yang memiliki kelebihan dana dengan pihak yang membutuhkan dana dengan cara memperjualbelikan sekuritas (Tandelilin, 2010: 26). Dengan demikian pasar modal juga bisa diartikan pasar untuk memperjualbelikan sekuritas yang umumnya memiliki umur lebih dari satu tahun, sedangkan tempat di mana terjadinya jual beli sekuritas disebut bursa efek. 
Oleh karena itu bursa efek merupakan arti pasar modal secara fisik. Di Indonesia terdapat satu bursa efek yaitu Bursa Efek Indonesia. Sejak tahun 2007 Bursa Efek Jakarta dan Bursa Efek Surabaya bergabung dan berubah nama menjadi Bursa Efek Indonesia.

Tandelilin (2010: 26) menyatakan pasar modal dapat berfungsi sebagai lembaga perantara (intermediaries). Fungsi ini menunjukkan peran penting pasar modal dalam menunjang perekonomian karena pasar modal dapat menghubungkan pihak yang membutuhkan dana dengan pihak yang mempunyai kelebihan dana. Disamping itu, pasar modal dapat mendorong terciptanya alokasi dana yang efisien karena dengan adanya pasar modal maka pihak yang kelebihan dana (investor) dapat memilih alternatif investasi yang memberikan return yang paling optimal. Berdasarkan Undang-Undang tentang Pasar Modal No. 8 Tahun 1995 memberikan pengertian Pasar Modal yang lebih spesifik yaitu kegiatan yang bersangkutan dengan Penawaran Umum dan perdagangan Efek, Perusahan Publik yang berkaitan dengan Efek yang diterbitkannya, serta lembaga dan profesi yang berkaitan dengan Efek.

Studi peristiwa menganalisis return tak normal (abnormal return) dari sekuritas yang mungkin terjadi di sekitar tanggal pengumuman dari suatu peristiwa. Abnormal return merupakan kelebihan dari return yang sesungguhnya terjadi terhadap return normal (Hartono, 2015: 647). Return normal merupakan return ekspektasi (return yang diharapkan investor). Dengan demikian return tidak normal (abnormal return) adalah selisih antara return sesungguhnya terjadi dengan return ekspektasi. Abnormal return mencerminkan pengaruh faktor-faktor 
tersebut dan oleh karena itulah abnormal return yang relevan untuk mengukur reaksi pasar terhadap pengumuman suatu informasi. Pasar akan menerima abnormal return apabila suatu pengumuman mempunyai kandungan informasi.

Right issue (HMETD) terkait erat dengan Preemptive Right (hak yang dimiliki oleh pemegang saham untuk mempertahankan persentase kepemilikannya). Sebagaimana diatur dalam Peraturan Bapepam Nomor IXD.1 Tahun 2003 tentang Hak Memesan Efek Terlebih Dahulu khususnya butir 2 disebutkan, bahwa apabila suatu perusahaan yang telah melakukan penawaran umum saham atau perusahaan publik bermaksud untuk menambah modal sahamnya, termasuk melalui penerbitan waran atau efek konversi, maka setiap pemegang saham harus diberi hak memesan efek terlebih dahulu sebanding dengan presentase pemilikan mereka.

Secara umum right issue ditujukan untuk memperkuat permodalan suatu perusahaan. Dana yang dihasilkan dari adanya right issue dapat digunakan untuk berbagai tujuan, misalnya melakukan ekspansi usaha, melunasi pembayaran hutang, atau akuisisi internal.

Pengumuman yang mengandung informasi akan direaksi oleh pasar pada saat pengumuman tersebut diterima. Right issue termasuk dalam salah satu jenis pendanaan ekternal (external financing), dimana perusahaan menghimpun dana guna memenuhi kebutuhan modal dengan menerbitkan saham baru. Pecking order theory menjelaskan adanya asimetri informasi yang dimiliki oleh manajemen perusahaan dan investor dalam kaitannya dengan sumber dana eksternal. Dalam hal ini, manajemen memiliki informasi yang lebih komprehensif tentang prospek 
perusahaan di masa yang akan datang. Peningkatan utang akan direspon sebagai suatu good news oleh investor, sedangkan penerbitan sekuritas ekuitas akan direspon sebagai suatu bad news (Dewi \& Wirama, 2017). Penerbitan saham berakibat pada turunnya dividen perlembar saham dan turunnya harga atau nilai saham karena jumlah saham bertambah. Sehingga pendanaan eksternal dilakukan dengan penerbitan saham baru akan menghasilkan respon negatif oleh pasar. Respon negatif tercermin dari adanya abnormal return yang negatif. Abnormal return yang diperoleh investor merupakan indikator untuk mengukur adanya reaksi pasar.

Hipotesis ini juga didukung oleh penelitian Kabir \& Roosenboom (2002) serta Suresha \& Naidu (2012) yang menemukan bahwa pasar berekasi negatif terhadap pengumuman right issue, karena right issue dianggap berita buruk yang menunjukan bahwa kinerja perusahaan sedang tidak baik.

$\mathrm{H}_{1}$ : Terdapat reaksi pasar yang negatif terhadap pengumuman right issue.

\section{METODE PENELITIAN}

Penelitian ini tergolong sebagai penelitian event study. Event study atau studi peristiwa merupakan studi yang mempelajari reaksi pasar terhadap suatu peristiwa (event) yang informasinya dipublikasikan sebagai suatu pengumuman. Hartono (2015: 623) Event study dapat digunakan untuk menguji kandungan informasi (information content) dari suatu pengumuman. Peristiwa yang diuji dalam penelitian ini adalah peristiwa pengumuman right issue yang akan diamati selama periode jendela yaitu 9 hari termasuk dengan event date. Waktu peristiwa 9 hari 
didasarkan pada penelitian terdahulu yang dilakukan oleh Apsari \& Yasa (2017) dimana untuk menghindari adanya tercampurnya informasi dari suatu peristiwa dengan informasi lainnya (confounding effect). Reaksi pasar diproksikan dengan abnormal return (cumulative abnormal return). Teknik analisis yang digunakan untuk menguji hipotesis adalah one-sample t-test. Hasil analisis kemudian diinterprestasikan untuk menjawab permasalahan. Langkah terakhir penelitian ini adalah membuat suatu simpulan dan saran penelitian.

Penelitian ini dilakukan di Bursa Efek Indonesia (BEI) pada perusahaan go public yang melakukan right issue selama periode 2011-2017, dengan mengakses website www.idx.co.id, www.e.bursa.com, dan finance.yahoo.com untuk mendapatkan informasi harga penutupan saham. Objek dari penelitian ini adalah reaksi investor dalam pasar modal dari pengumuman right issue di Bursa Efek Indonesia. Reaksi pasar diukur dengan menggunakan abnormal return.

Populasi dalam penelitian ini adalah seluruh perusahaan go public yang terdaftar di Bursa Efek Indonesia yang melakukan right issue selama periode 2011-2017. Sampel adalah bagian dari jumlah dengan karakteristik yang dimiliki oleh populasi tersebut (Sugiyono, 2017: 81). Syarat utama dalam pengambilan sampel suatu populasi adalah sampel harus mewakili populasi dan harus dalam bentuk kecil. Sampel dalam penelitian ini adalah seluruh perusahaan go public yang terdaftar di Bursa Efek Indonesia yang right issue selama periode 2011-2017 yang memenuhi persyaratan kriteria sampling.

Studi peristiwa merupakan studi yang mempelajari reaksi pasar terhadap suatu peristiwa (event) yang informasinya dipublikasikan sebagai suatu 
pengumuman. Right issue merupakan upaya perusahaan untuk menambah jumlah saham yang beredar. Diharapkan dengan penambahan jumlah lembar saham di bursa akan meningkatkan frekuensi perdagangan saham tersebut atau meningkatkan likuiditas saham (Harianto \& Sudomo, 1998). Periode pengamatan yang digunakan dalam penelitian ini adalah periode amatan selama 9 hari yaitu 4 hari sebelum pengumuman ( $\mathrm{t}-4), 1$ hari saat pengumuman (event date, $\mathrm{t} 0$ ) dan 4 hari setelah tanggal pengumuman $(\mathrm{t}+4)$. Tanggal pengumuman right issue yaitu t0 dipilih pada tanggal RUPSLB perusahaan yang melakukan right issue. Alasan pengambilan periode 9 hari yaitu 4 hari sebelum pengumuman (t-4), 1 hari saat pengumuman (event date, $\mathrm{t} 0)$ dan 4 hari sesudah tanggal pengumuman $(\mathrm{t}+4)$ adalah bertujuan menghindari adanya corporate action diluar peristiwa right issue seperti peristiwa pengumuman pembagian dividen tunai, dividen saham, warran atau saham bonus, dan berbagai informasi lain yang dapat mempengaruhi hasil penelitian.

\section{HASIL DAN PEMBAHASAN}

Deskripsi variabel penelitian menyampaikan informasi mengenai karakteristik variabel-variabel penelitian yang terdiri dari jumlah pengamatan, nilai minimum, nilai maksimum, nilai rata dan standar deviasi. Tabel 2 memperlihatkan hasil analisis statistik deskriptif variabel penelitian. 
Tabel 2.

Hasil Uji Statistik Deskriptif

\begin{tabular}{lccccc}
\hline & $\mathrm{N}$ & Minimum & Maximum & Mean & Std. Deviation \\
\hline CAR & 103 & -0.5050 & 0.9666 & 0.012486 & 0.1412849 \\
Actual_Return & 103 & -0.4965 & 0.9873 & 0.011619 & 0.1426349 \\
Expected_Return & 103 & -0.0999 & 0.0736 & -0.000871 & 0.0282547 \\
Valid N (listwise) & 103 & & & & \\
\hline Sumber: Data diolah, 2018 & & & & &
\end{tabular}

Tabel 2 menunjukkan Cumulative abnormal return (CAR) secara keseluruhan dengan 103 perusahaan yang digunakan selama sembilan hari pengamatan, diperoleh nilai rata-rata CAR sebesar 0,012486, yang berarti selama sembilan hari pengataman investor memiliki CAR dengan rata-rata sebesar 0,01248, dengan nilai standar deviasi sebesar 0,1412849. Nilai CAR paling rendah (minimum) adalah sebesar -0,5050 yang dimiliki oleh PT SMR Utama Tbk dengan kode SMRU dan nilai CAR yang paling tinggi (maksimum) adalah sebesar 0,9666 yang dimiliki oleh PT Indoritel Makmur Internasional Tbk dengan kode DNET.

Hasil analisis deskriptif menunjukkan actual return secara keseluruhan dengan 103 perusahaan yang digunakan selama sembilan hari pengamatan, diperoleh nilai rata-rata actual return sebesar 0,011619, yang berarti selama sembilan hari pengataman investor memiliki actual return dengan rata-rata sebesar 0,011619, dengan nilai standar deviasi sebesar 0,1426349. Nilai actual return paling rendah (minimum) adalah sebesar $-0,4965$ yang dimiliki oleh PT SMR Utama Tbk dengan kode SMRU dan nilai actual return yang paling tinggi (maksimum) adalah sebesar 0,9873 yang dimiliki oleh PT Indoritel Makmur Internasional Tbk dengan kode DNET. 
Pita Qurnia Amir dan I G.N. Agung Suaryana. Reaksi ...

Hasil analisis deskriptif menunjukkan expected return secara keseluruhan dengan 103 perusahaan yang digunakan selama sembilan hari pengamatan, diperoleh nilai rata-rata expected return sebesar $-0,000871$, yang berarti selama sembilan hari pengataman investor memiliki expected return dengan rata-rata sebesar -0,000871, dengan nilai standar deviasi sebesar 0,282547. Nilai expected return paling rendah (minimum) sebesar -0,0999 yang dimiliki oleh PT Hero Supermarket Tbk dengan kode HERO dan nilai expected return yang paling tinggi (maksimum) adalah sebesar 0,0736 yang dimiliki oleh PT Hanjaya Mandala Sampoerna Tbk dengan kode HMSP.

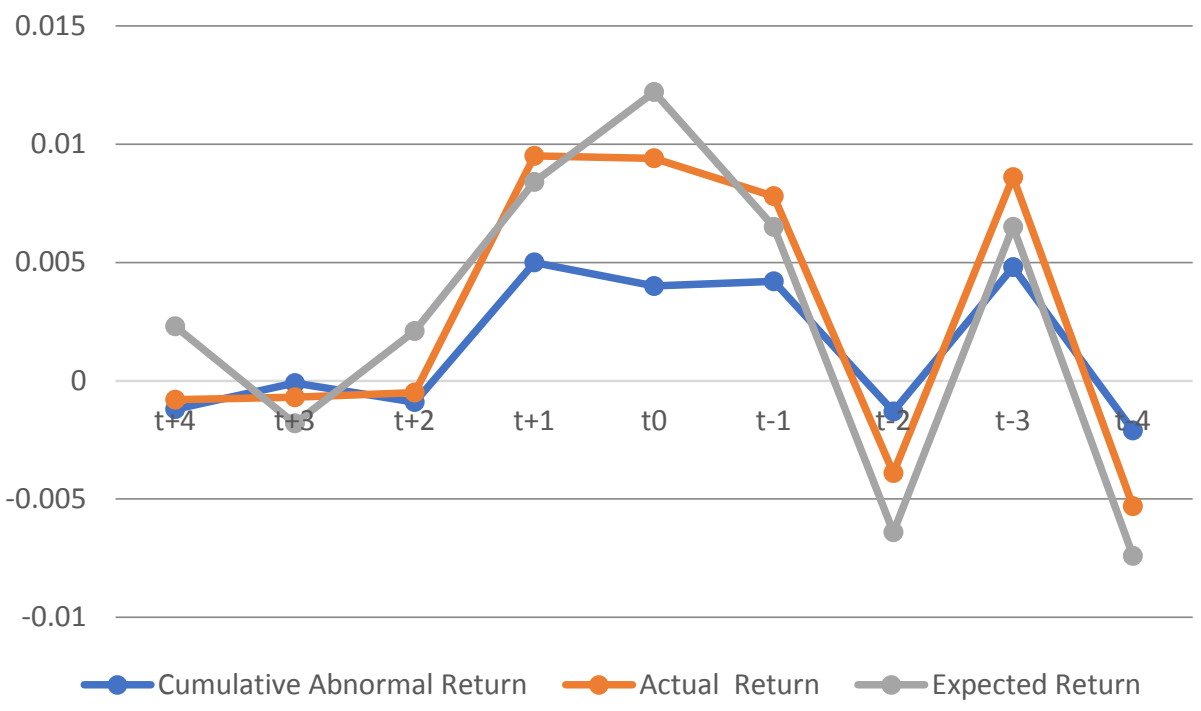

Gambar 2. Grafik Rata-Rata Cumulative Abnormal Return, Actual Return Sumber: Data diolah, 2018 dan Expected Return

Gambar 2 menunjukkan fluktuasi rata-rata cumulative abnormal return, actual return dan expected return pada periode pengamatan peristiwa Pengumuman right issue. Nilai cumulative abnormal return tertinggi terjadi pada saat $\mathrm{t}+1$ yaitu dengan nilai rata-rata sebesar 0,0050 dan terendah pada saat $\mathrm{t}-4$ 
yaitu dengan nilai rata-rata sebesar $-0,0021$. Nilai actual return tertinggi terjadi pada saat t0 yaitu dengan nilai rata-rata sebesar 0,0054 dan terendah pada saat $\mathrm{t}-4$ yaitu dengan nilai rata-rata sebesar -0,0032. Nilai Expected Return tertinggi terjadi pada saat $\mathrm{t}+4$ yaitu dengan nilai rata-rata sebesar 0,0031 dan terendah pada saat t-2 dengan nilai rata-rata sebesar $-0,0025$.

Berdasarkan hasil uji one sample t-test selama 9 hari periode pengamatan, dengan tujuan untuk memperlihatkan apakah terdapat abnormal return yang signifikan di sepanjang event window, dengan mengukur tingkat signifikansi cumulative abnormal return (CAR), maka diperoleh hasil seperti yang disajikan pada Tabel 3.

Tabel 3.

Hasil Uji t

\begin{tabular}{|c|c|c|c|c|c|c|}
\hline & \multirow[b]{2}{*}{$\mathrm{t}$} & \multirow[b]{2}{*}{$\mathrm{df}$} & \multirow[b]{2}{*}{ Sig. (2-tailed) } & \multirow{2}{*}{$\begin{array}{c}\text { Mean } \\
\text { Difference }\end{array}$} & \multicolumn{2}{|c|}{$\begin{array}{l}\text { 95\% Confidence Interval of the } \\
\text { Difference }\end{array}$} \\
\hline & & & & & Lower & Upper \\
\hline CAR & 0.897 & 102 & 0.372 & 0.0124864 & -0.015126 & 0.040099 \\
\hline
\end{tabular}

Sumber: Data diolah, 2018

Berdasarkan tabel one sample t-test dihasilkan cumulative abnormal return (CAR) selama 9 hari periode pengamatan memperoleh nilai $t=0,897$ dengan nilai signifikansi sebesar $0,372>\alpha(0,05)$, menunjukkan bahwa tidak terdapat reaksi pasar terhadap pengumuman right issue.

Tabel 4.

Hasil One Sample t-test Abnormal Return

\begin{tabular}{ccccc}
\hline Periode & Rata-rata & t-hitung & Signifikansi & Keterangan \\
\hline T-4 & $-0,0021184$ & $-0,00545$ & 0,576 & Tidak Signikan \\
T-3 & 0,0048515 & 0,01254 & 0,199 & Tidak Signikan \\
T-2 & $-0,0013398$ & $-0,00357$ & 0,713 & Tidak Signikan \\
T-1 & 0,0042495 & 0,01405 & 0,151 & Tidak Signikan \\
T0 & 0,0039981 & 0,00118 & 0,226 & Tidak Signikan \\
T+1 & 0,0050243 & 0,01006 & 0,302 & Tidak Signikan \\
T+2 & $-0,0009398$ & $-0,00203$ & 0,835 & Tidak Signikan \\
T+3 & $-0,0000641$ & $-0,00016$ & 0,987 & Tidak Signikan \\
T+4 & $-0,0011709$ & $-0,00272$ & 0,783 & Tidak Signikan \\
\hline
\end{tabular}

Sumber: Data diolah, 2018 
Hasil uji perhari ini juga menunjukkan bahwa tidak terdapat kandungan informasi pada peristiwa pengumuman right issue yang ditunjukkan dengan tidak adanya abnormal return yang signifikan pada empat hari sebelum, saat, sampai dengan empat hari setelah pengumuman right issue, yang berarti hipotesis 1 ditolak, membuktikkan bahwa tidak terdapat reaksi pasar terhadap pengumuman right issue pada perusahaan go public yang terdaftar di Bursa Efek Indonesia selama periode 2011-2017.

Investor akan mempertimbangkan informasi dari suatu peristiwa, namun persepsi dari para investor atas informasi baru tidak selalu sama sehingga menimbulkan reaksi yang berbeda diantara para investor tersebut. Gabungan dari seluruh reaksi investor atas informasi baru yang menyangkut suatu saham akan membentuk suatu reaksi pasar atas informasi baru tersebut. Penelitian ini bertujuan untuk mengetahui reaksi pasar terhadap Pengumuman Right Issue. Reaksi pasar dapat diproksikan melalui abnormal return, yang dihitung menggunakan market-adjusted model. Berdasarkan hasil uji hipotesis yang dilakukan dengan one sample t-test, didapatkan bahwa hipotesis 1 ditolak, yang berarti tidak ada reaksi pasar terhadap pengumuman right issue, dengan nilai signifikansi CAR sebesar $0,372>\alpha(0,05)$, serta tidak adanya abnormal return yang signifikan di sepanjang event window yaitu selama 9 hari periode pengamatan berdasarkan hasil one sample t-test yang dilakukan pada tiap-tiap hari periode peritiwa. Hal ini terjadi dikarenakan pasar sudah mengantisipasi informasi tersebut sebelum pengumuman resmi melalui Rapat Umum Pemegang Saham 
Luar Biasa (RUPSLB) dikeluarkan sehingga pengumuman itu tidak mempengaruhi preferensi investor dalam pembuatan keputusan investasinya.

Sesuai dengan Peraturan Bapepam Nomor IX.D.1 Tahun 2003 tentang Hak Memesan Efek Terlebih Dahulu (HMETD) tentang Hak Memesan Efek Terlebih Dahulu (HMETD) disebutkan bahwa untuk dapat melaksanakan RUPSLB dalam rangka penambahan modal dengan HMETD, emiten harus telah mengajukan Pernyataan Pendaftaran dan dokumen pendukungnya kepada Bapepam-LK dalam bentuk serta mencakup informasi yang ditetapkan dalam Penawaran Umum dengan Hak Memesan Efek Terlebih Dahulu sesuai dengan Peraturan Bapepam Nomor IX. D.2 Tahun 2000 tentang Pedoman Mengenai Bentuk dan Isi Pernyataan Pendaftaran dalam Rangka Penerbitan Hak Memesan Efek Terlebih Dahulu tentang Pedoman Mengenai Bentuk dan Isi Pernyataan Pendaftaran dalam Rangka Penerbitan Hak Memesan Efek Terlebih Dahulu, hal ini merupakan pengumuman oleh perusahaan kepada para pemegang saham, yang dilakukan selambat-lambatnya 28 (dua puluh delapan) hari sebelum RUPSLB, dengan demikian ada kemungkinan pasar telah bereaksi pada saat pengumuman sebelum RUPSLB tersebut akan diadakan sehingga disekitaran tanggal pengumuman resmi melalui RUPSLB yaitu selama 9 hari periode pengamatan, 4 hari sebelum, saat, dan 4 hari setelah pengumuman, pasar tidak bereaksi. Hal tersebut terbukti dengan adanya berita yang terbit mengenai salah satu perusahaan yang akan mengadakan RUPSLB berkaitan dengan rencana right issue yang akan dilakukan. 
PT Trada Alam Minera Tbk (TRAM) berencana untuk menambah modal dengan Hak Memesan Efek Terlebih Dahulu (HMETD) atau rights issue senilai total Rp 6 triliun dalam rangka mencari dana untuk mengakuisisi PT SMR Utama Tbk (SMRU). Perseroan akan menggelar Rapat Umum Pemegang Saham Luar Biasa (RUPSLB) terkait aksi korporasi ini. Melansir keterbukaan informasi yang diterbitkan perseroan di situs Bursa Efek Indonesia (BEI), perseroan bermaksud menerbitkan sebanyak-banyaknya 40 miliar saham baru dengan nilai nominal Rp100 per saham. Angka ini, setara dengan 80,43 persen dari modal ditempatkan dan disetor penuh dalam Perseroan.Terkait rencana peningkatan modal dengan HMETD ini, perseroan akan meminta restu terlebih dahulu kepada para pemegang saham dalam RUPSLB yang akan diadakan pada tanggal 7 November 2017 (www.bareksa.com, 2017)

Ada kemungkinan faktor lain diluar informasi pengumuman right issue yang menyebabkan tidak terdapatnya abnormal return yang signifikan. Faktorfaktor tersebut antara lain nilai intrinsik perusahaan tersebut seperti aktiva, pendapatan, deviden dan prospek perusahaan yang dapat mempengaruhi dalam proses penilaian saham selain harga (Sunariyah, 2000: 154), selain itu kondisi perekonomian secara makro, kebijakan pemerintah lainnya, kondisi persaingan dan situasi politik juga turut mempengaruhi kebijakan investor dalam menentukan keputusannya.

Right issue merupakan salah satu jenis corporate action yang dilakukan oleh perusahaan dengan melakukan penawaran umum terbatas atas saham baru yang dikeluarkan perusahaan kepada pemegang saham lama. Right issue 
merupakan salah satu peristiwa yang dapat digunakan untuk melihat ada tidaknya rekasi pasar. Hasil dari penelitian ini sejalan dengan penelitian-penelitian yang dilakukan oleh Budiarto \& Baridwan (1999), yang membuktikan bahwa rata-rata abnormal return di sekitar tanggal pengumuman secara statistik tidak signifikan. Firstolino (2013) juga menyimpulkan bahwa tidak ada pengaruh dari right issue yang signifikan dilihat dari abnormal return yang berarti pengumuman right issue tidak direspon oleh investor. Hal ini menunjukkan bahwa pengumuman right issue tidak direspon oleh investor dikarenakan oleh beberapa faktor yaitu, sebagian besar perusahaan yang menerbitkan right issue bukan termasuk dalam saham blue chip atau 50 kategori saham yang paling aktif dalam bursa efek indonesia serta perubahan harga saham diakibatkan oleh penyesuaian volume saham karena adanya penambahan saham-saham baru, jadi bukan karena ada kandungan informasi pada pengumuman right issue yang mampu mengubah preferensi keputusan investor.

Penelitian ini menghasilkan simpulan mengenai bagaimana reaksi pasar modal terhadap Pengumuman Right Issue. Berdasarkan analisis yang dilakukan, hasil dalam penelitian ini tidak mendukung pecking order theory yang menyatakan right issue akan menghasilkan respon pasar negatif karena merupakan pendanaan eksternal yang dilakukan perusahaan dengan cara menerbitkan saham baru yang akan menurunkan harga atau nilai saham, hal ini dibuktikan dengan tidak adanya reaksi pasar dimana tidak terdapat abnormal return yang signifikan di sekitar tanggal pengumuman right issue. Hasil penelitian ini mendukung penelitian yang dilakukan oleh Yanti (2011) yang menunjukkan 
bahwa tidak ada respon pasar yang signifikan terhadap pengumuman right issue. Penelitian ini juga mendukung penelitian yang dilakukan oleh Dewi \& Putra (2013) yang menyatakan bahwa tidak terdapat perbedaan abnormal return sebelum dan sesudah pengumuman right issue.

Hasil dari penelitian ini dapat digunakan sebagai pertimbangan terhadap pengambilan keputusan yang tepat dalam berinvestasi oleh pihak yang berkepentingan di pasar modal khususnya bagi investor untuk bisa mendapatkan keuntungan dan meminimalkan resiko yang bisa saja terjadi dalam berinvestasi terkait dengan peristiwa pengumuman right issue. Penelitian selanjutnya diharapkan dapat menggunakan model perhitungan abnormal return lainnya selain menggunakan market-adjusted model, membedakan jenis perusahaan yang diteliti berdasarkan sektornya maupun dari segi tujuan penggunaan dana hasil right issue yang dilakukan perusahaan.

\section{SIMPULAN}

Berdasarkan hasil pengujian terhadap peristiwa pengumuman right issue menggunakan one sample t-test selama 9 hari periode pengamatan yang telah diuraikan maka dapat disimpulkan bahwa pasar tidak bereaksi atas pengumuman right issue, ditunjukkan dengan tidak terdapatnya abnormal return yang signifikan di sekitar tanggal pengumuman right issue. Dengan demikian dapat dikatakan bahwa pengumuman right issue tidak memiliki kandungan informasi dan tidak memengaruhi prefensi investor dalam mengambil keputusan di pasar modal Indonesia. 
Saran-saran yang dapat diberikan berkaitan dengan hasil penelitian serta untuk kesempurnaan penelitian selanjutnya yaitu disarankan untuk meneliti pada saat pengumuman pertama kali dikeluarkan sebelum dipublikasikan secara resmi melalui Rapat Umum Pemegang Saham Luar Biasa (RUPSLB). Selain itu, disarankan agar menggunakan model-model perhitungan abnormal return yang lain untuk hasil yang lebih beragam seperti market model dan mean-adjusted model, kemudian juga dapat dibedakan dari jenis perusahaan yang diteliti misalnya berdasarkan sektor perusahaan, serta dari segi tujuan, karena penggunaan hasil dana right issue yang berbeda oleh masing-masing perusahaan kemungkinan akan memberikan hasil yang tidak sama.

Bagi investor berdasarkan hasil analisis ini, dengan melihat tidak terdapatnya abnormal return yang signifikan di sekitar tanggal pengumuman right issue maka saran yang dapat diberikan untuk pihak investor adalah sebaiknya tidak mengambil keputusan investasi saham jangka pendek pada perusahaanperusahaan yang melakukan right issue atau disarankan untuk tidak membeli saham di sekitaran tanggal pengumuman right issue tersebut agar investasi saham yang dilakukan bisa lebih menguntungkan dan mengurangi resiko yang mungkin bisa terjadi apabila mengambil keputusan yang kurang tepat.

\section{REFERENSI}

Alisabri, H. M. (2004). The Impact of Announcements of Rights Issues on The Share Prices of the Companies Traded on the Colombo Stock Exchange - An Event Study Analysis. Journal of Management, 2(1), 14-25.

Apsari, I. A. W. P., \& Yasa, G. W. (2017). Analisis Reaksi Pasar Terhadap Pengumuman Right Issue pada Perusahaan Go Public yang Tercatat Di BEI. E-Jurnal Akuntansi Universitas Udayana, 18(2), 1343-1368. 
Babu, S. (2018). A Study On The Effect Of Rights Issue Announcement On Companies Listed In The National Stock Exchange. International Journal of Advanced Research and Development, 3(2), 275-277.

Bareksa.com. (2017). Rencana Rights Issue, TRAM Akan Gelar RUPSLB 7 November. https://www.bareksa.com/id/text/2017/11/03/rencana-rightsissue-tram-akan-gelar-rupslb-7-november/17243/news.

Budiarto, A., \& Baridwan, Z. (1999). Pengaruh Pengumuman Right Issue terhadap Tingkat Keuntungan dan Likuiditas Saham di Bursa Efek Jakarta. Jurnal Riset Akuntansi Indonesia, 2(1), 91-116.

Darmadji, T., \& Fakhruddin, H. M. (2006). Pasar Modal di Indonesia Pendekatan Tanya Jawab. Jakarta: Salemba Empat.

Dewi, N. P. S., \& Putra, I. N. W. A. (2013). Pengaruh Pengumuman Right Issue Pada Abnormal Return Dan Volume Perdagangan Saham. E-Jurnal Akuntansi Universitas Udayana, 3(3), 163-178.

Dewi, S. M. Y., \& Wirama, D. G. (2017). Pecking Order Theory: Pengaruh Profitabilitas dan Pertumbuhan Perusahaan pada Keputusan Pendanaan Perusahaan. E-Jurnal Akuntansi Universitas Udayana, 18(3), 2423-2450.

Endriani, S. (2015). Pengaruh Pengumuman Right Issue Terhadap Return Saham Pada Perusahaan Manufactur Yang Terdapat Di Bursa Efek Indonesia. Neraca Jurnal Pendidikan Ekonomi, 1(1), 1-7.

Fahmi, I., \& Saputra, M. (2013). Analysis of Profitability Ratio in Publishing Right Issue Decision at Indonesia Stock Exchange. International Journal of Business and Social Science, 4(4), 272-280.

Firstolino, M. (2013). Pengaruh Right Issue Terhadap Abnormal Return Dan Volume Perdagangan Saham Perusahaan Yang Terdaftar Di Bursa Efek Indonesia (BEI) Tahun 2013. Jurnal Akuntansi UNESA, 4(2), 1-19.

Ginglinger, E., \& Gajewski, J.-F. (2007). Seasoned Equity Issues in a Closely Held Market: Evidence from France. European Finance Review2, 6(3), 291319.

Harianto, F., \& Sudomo, S. (1998). Perangkat dan Teknik Analisis Investasi. Jakarta: PT. Bursa Efek Indonesia.

Hartono, J. (2015). Teori Portofolio dan Analisis Investasi (Edisi Kese). Yogyakarta: BPFE Yogyakarta.

Kabir, R., \& Roosenboom, P. (2002). Can The Stock Market Anticipate Future Operating Performance? Evidence From Equity Rights Issues. 
Kendirli, S., \& Elmali, M. E. (2016). The Effects of Right Offering Announcements on Returns of Shares of Deposit Banks Traded in Istanbul Stock-Exchange. Journal of Economic Development, Environment and People, 5(1), 74-82.

Khoso, A. A., Ahmedani, M. M., Kazi, A. S., Ahmed, M., \& Siddiqui, H. (2016). The Effect of Right Issue Announcement on Share Prices of Companies Listed at KSE. International Journal of Multidisciplinary Research and Development, 3(7), 147-156.

Komaling, A. M. (2010). Reaksi Pasar Atas Secondary Right Issue Pada Perusahaan Yang Go Publik Di Indonesia. Jurnal EMBA, 1(3), 118-128.

Kontan.co.id. (2018). Menakar Saham Rights Issue di Bursa Efek. https://investasi.kontan.co.id/news/menakar-saham-rights-issue-di-bursaefek.

Kusuma, P. S. A. J., \& Suryanawa, I. K. (2015). Analisis Komparatif Kinerja Saham Sebelum Dan Sesudah Pengumuman Right Issue. E-Jurnal Akuntansi Universitas Udayana, 12(3), 566-581.

Lianawati, N. K., \& Darmayanti, N. P. A. (2015). Reaksi Pasar Terhadap Peristiwa Right Issue di Bursa Efek Indonesia. E-Jurnal Manajemen Unud, 4(12), 4392-4418.

Malhotra, M. M., M., T., \& Gopalaswamy, A. K. (2012). Liquidity Changes Around Bonus And Rights Issue Announcements: Evidence From Manufacturing And Service Sectors in India. International Journal of Money Banking and Finance, 1(1), 28-34.

Manullang, A. (2008). Pengaruh RIght Issue Terhadap Volume Perdagangan Saham dan Abnormal Return di Bursa Efek Jakarta Tahun 2000-2026. Jurnal Fokus Ekonomi, 3(1), 99-106.

Mariko, B. J., \& Theuri, J. M. (2016). Effect of Information Adjustment Time on Share Prices for Firm' S Listed on the Nairobi Security Exchange Effect of Information Adjustment Time on Share Prices for Firm' S Listed on the Nairobi Security Exchange. American Journal Of Finance, 1(3), 54-70.

Miglani, P. (2011). An Empirical Analysis of the Impact of Hedge. Journal of Arts, Science \& Commerce2, 2(4), 169-176.

Badan Pengawas Pasar Modal. Keputusan Ketua Badan Pengawas Pasar Modal Nomor KEP-08/PM/2000 Tentang Perubahan Peraturan Nomor IX.D.2 Tentang Pedoman Mengenai Bentuk dan Isi Pernyataan Pendaftaran Dalam Rangka Penerbitan Hak Memesan Efek Terlebih Dahulu (2000). 
Badan Pengawas Pasar Modal. Keputusan Ketua Badan Pengawas Pasar Modal Nomor: KEP-26/PM/2003 Tentang Hak Memesan Efek Terlebih Dahulu (2003).

Myers, S. C. (1984). The Capital Structure Puzzle. The Journal of Finance, 39(3), 1185-1208.

Ogada, A., \& Kalunda, E. (2017). Impact of Rights Issue on Share Returns of Firms Listed on The Nairobi Securities Exchange, Kenya. IOSR Journal of Business and Management, 19(8), 54-62.

Otieno, O. D., \& Ochieng, D. E. (2015). The effects of Rights Issue Announcements on Stock Returns for Firms Listed at the Nairobi Securities Exchange. International Journal of Education and Research, 3(9), 411-426.

Presiden Republik Indonesia. Undang-Undang Republik Indonesia Nomor 8 Tahun 1995 Tentang Pasar Modal. (1995).

Rizaldi, Y. (2014). Analisis Perbedaan Return Saham Sebelum dan Sesudah Pengumuman Right Issue di Bursa Efek Indonesia Tahun 2010-2013. Jurnal Ilmiah Mahasiswa STKIP PGRI Sumatera Barat, 1-13.

Shahid, H., Xia, X., Mahmood, F., \& Usman, M. (2010). Announcement Effects of Seasoned Equity Offerings in China. International Journal of Economics and Finance, 2(3), 163-169.

Solikhin, A. (2000). Analisis Dampak Pengumuman Right Issue terhadap Reaksi Pasar di Bursa Efek Jakarta. Universitas Diponegoro Semarang.

Sugiyono. (2017). Metode Penelitian Kuantitatif, Kualitatif, dan R\&D. Bandung: Alfabeta.

Sunariyah. (2000). Pengantar Pengetahuan Pasar Modal. Yogyakarta: UPP AMP. YKPN.

Suresha, B., \& Naidu, G. (2012). An Empirical Study on Announcement Effect of Right Issue on Share Price Volatility and Liquidity and Its Investors in Bangalore With Special Reference To Cnx Nifty Stocks of NSE. EXCEL International Journal of Multidisciplinary Management Studies, 2(7), 41-58.

Tambunan, A. P. (2007). Menilai Harga Wajar Saham. Jakarta: Elex Media Komputindo.

Tandelilin, E. (2010). Portofolio dan Investasi Edisi Kesatu. Yogyakarta: Kanisius. 
Ventoruzzo, M. (2013). Issuing New Shares and Preemptive Rights: A Comparative Analysis. Richmond Journal Of Global Law \& Business, 12(4), $517-542$.

Widaryanti. (2006). Perbedaan Antara Sebelum Dan Sesudah Pengumuman Right Issue Terhadap Abnormal Return Dan Trading Volume Activity Pada Perusahaan Publik Di Bursa Efek Jakarta. Jurnal Fokus Ekonomi, 1(1), 3846.

Yusuf, S. D., Djazuli, A., \& Susanto, H. M. H. (2009). Analisis Reaksi Investor Terhadap Pengumuman Right Issue Di Bursa Efek Jakarta. Jurnal Wacana, 12(4), 792-814. 